\title{
Optical properties of alumina films by sol gel acrylamide route
}

\author{
G. Ramanathan ${ }^{1}$, K.R.Murali ${ }^{2}$ \\ ${ }^{1}$ Dept .of Physics, Sri SaiRam Engineering College, Chennai, 600044 India \\ ${ }^{2}$ Department of Theoretical physics, University of Madras, Chennai, India.
}

\begin{abstract}
:
A new acrylamide route was applied to prepare alumina films by using aluminum chloride as a starting material and ammonium persulphate solution as the gelling agent. The XRD results show that the films are amorphous for the post anneals temperatures up to $300{ }^{\circ} \mathrm{C}$, beyond this temperature; peaks corresponding to $\gamma-\mathrm{Al}_{2} \mathrm{O}_{3}$ are observed.XPS studies indicated the peaks corresponding to the $\mathrm{Al} 2 \mathrm{p}$ spectra of films after annealing at different temperatures. The FTIR spectra reveal absorption bands of Al-O and to lattice. The absorption co-efficient was $10^{14} \mathrm{~cm}^{-}$

${ }^{1}$.Refractive index was in the range of 1.71 to 1.61 with increase of wavelength from $250-500 \mathrm{~nm}$. Optical band gap value was around 5.40-5.75 eV with increase of annealing temperature.
\end{abstract}

Keywords: sol gel method, alumaina films, acrylamide

Corresponding Author: Dr.G.Ramanathan.

Email: gramsriram@gmail.com

\section{Introduction}

Alumina films have more electrical, optical and wear resistant applications.Aluminium oxide (AL2O3) coating have more popular for their high dielectric strength, exceptional stability and durability against hostile environment and high transparency down to $250 \mathrm{~nm}$.During the last few years $\mathrm{Al}_{2} \mathrm{O}_{3}$ coating have been widely used for their practical applications such as refractory coating, microelectronic devices,capacitance,humidity sensors and also in heat sinks in IC's and passivation of metal surface. Alumina films can be prepared by a variety of techniques such as physical vapors deposition (PVD) [1,2] chemical vapors deposition (CVD) [3,5],spray pyrolysis,thermal evaporation sputtering, spray pyrolysis and sol gel etc. Among these, the sol gel 
methods are important alternative for conventional processes. The major advantages of these techniques are low cost instrumentation with high deposition efficiency. Generally the aluminum alkoxides such as aluminum see-butoxide and aluminum iso-propoxide are chosen to prepare $\mathrm{Al}_{2} \mathrm{O}_{3}$ films by sol gel method [6,8]. However these usual precursors are expensive for the fabrication of ceramics films are harmful to people health. So we prepare alumina films form a new approach. In this work $\mathrm{Al}_{2} \mathrm{O}_{3}$ thin films have been prepared by sol gel dip coating method using the acrylamide route.

\section{Experimental:}

$\mathrm{Al}_{2} \mathrm{O}_{3}$ thin films were deposited by the sol gel dip coating method adopting the following procedure.Aluminium chloride $(99.99 \%)$ was dissolved in triple distilled water to form a $0.2 \mathrm{M}$ solution. This solution was maintained at $70{ }^{\circ} \mathrm{C}$ and the $\mathrm{pH}$ of the solution was changed to 9 by adding sodium hydroxide solution. To this mixture acrylamide were one after the other. Finally a small quantity of gelling agent ammonium persulphate was added till a viscous solution was obtained. The cleaned glass slides $(2.5 \times 7.5 \mathrm{~cm})$ were inserted inside this solution and withdrawn at the rate of $0.5 \mathrm{~cm} / \mathrm{min}$. The films deposited on the glass substrate were dried in air at $100{ }^{\circ} \mathrm{C}$ for 30 min, followed by heating at different temperature in the range of $300-550{ }^{\circ} \mathrm{C}$ for 30 minutes. The films were characterized by X-ray diffraction using Phillips X-ray diffraction unit and cuk $\alpha$ radiation.XPS studies were studied with scientific mkII system using Mgk $\alpha$-radiation. An optical transmission spectrum was recorded at room temperature using U3400 Hitachi UV-Vis-NIR spectrophotometer.

\section{$\underline{\text { Results and Discussion: }}$}

The XRD pattern of the films sintered at different temperatures are shown in figure-1.These pattern show that films annealed at $300 \mathrm{C}$ are amorphous and as the annealing temperature increased from $400 \mathrm{C}$ to $550 \mathrm{C} \gamma-\mathrm{Al}_{2} \mathrm{O}_{3}$ exhibited preferential orientation in the (311) direction. All the peaks belonging to $\gamma-\mathrm{Al}_{2} \mathrm{O}_{3}$ phase are well matched with the data base in JCPDSC (card\#41-1432). The XPS survey scan spectra of the films heat treated at different temperature as shown in figure-2.XPS spectra indicated the films post annealed at $550 \mathrm{C}$ exhibit a single peak with a binding energy of 74.1 $\mathrm{eV}$ (characteristics of $\mathrm{Al}_{2} \mathrm{O}_{3}$ ) while those post annealed at lower temperatures have two peaks separated by $3 \mathrm{eV}$ which is attributed to photoemission of two separate $\mathrm{Al}_{2} \mathrm{O}_{3}$ phase present on the 
surface. The latter is due to the effect of different electrostatic charging during photoemission from both $\mathrm{Al}_{2} \mathrm{O}_{3}$ phase.

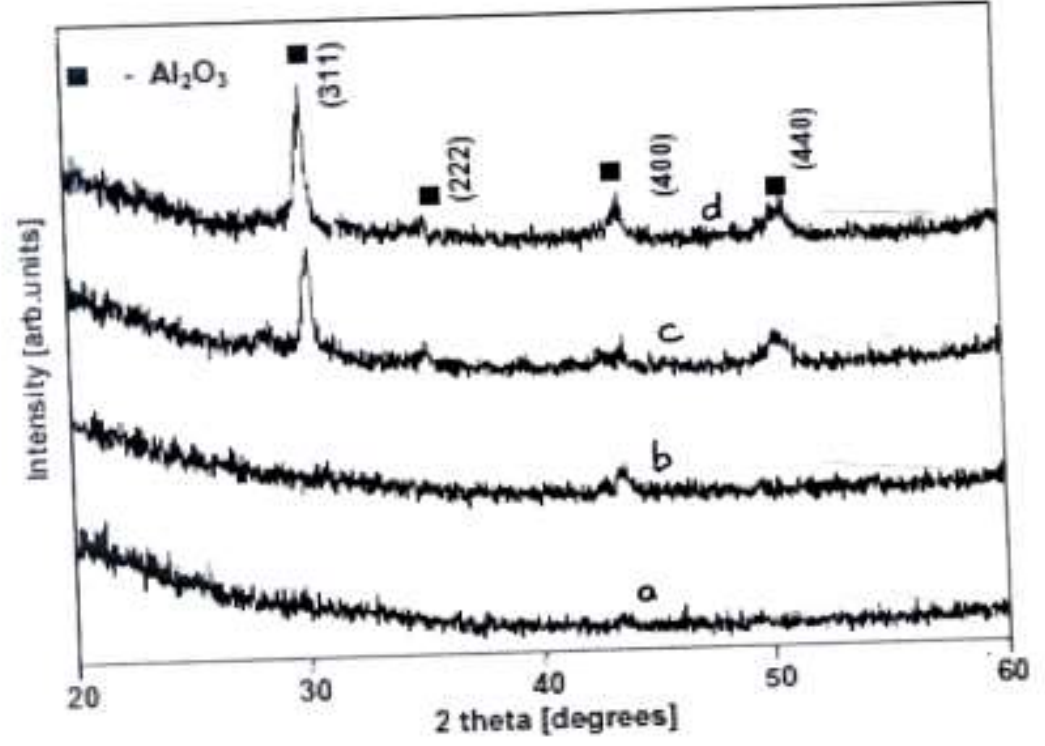

Fig.1 - XRD pattern of $\mathrm{Al}_{2} \mathrm{O}_{3}$ films post annealed at different temperatures (a) $300^{\circ} \mathrm{C}$ (b) $350^{\circ} \mathrm{C}$ (c) $450^{\circ} \mathrm{C}$ (d) $550^{\circ} \mathrm{C}$

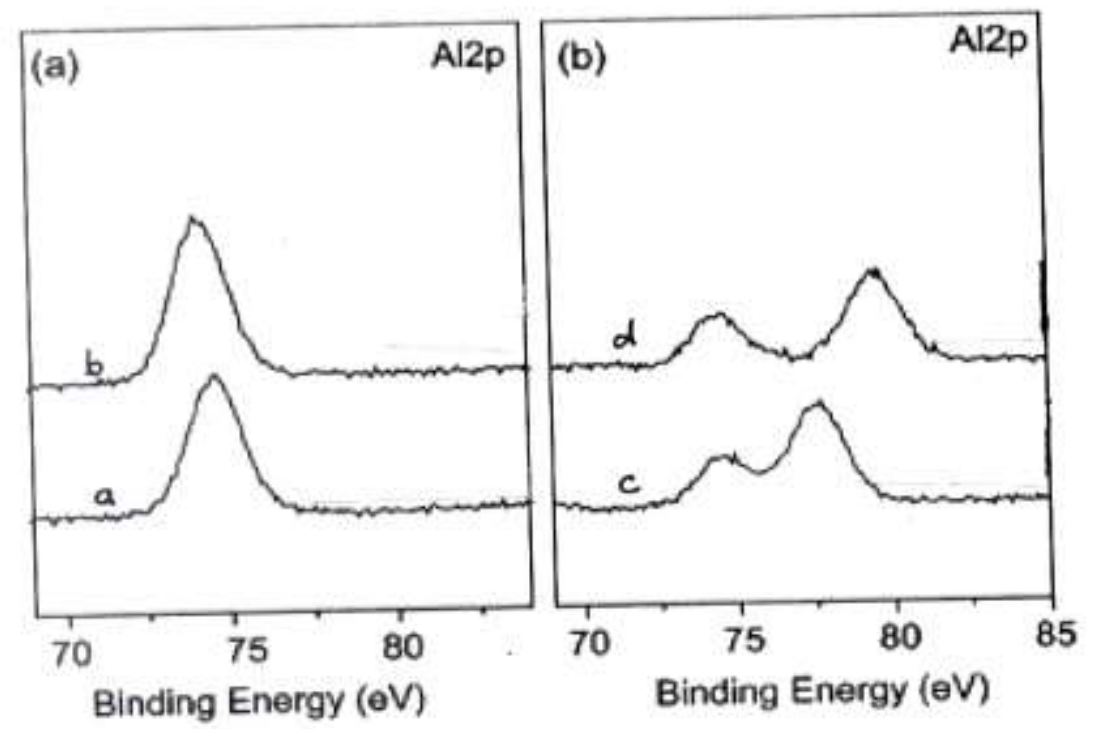

Fig.2 - XPS spectra of $\mathrm{Al}_{2} \mathrm{O}_{3}$ films post annealed at different temperatures

(a) $550^{\circ} \mathrm{C}$ (b) $450^{\circ} \mathrm{C}$ (c) $350^{\circ} \mathrm{C}$ (d) $300^{\circ} \mathrm{C}$ 


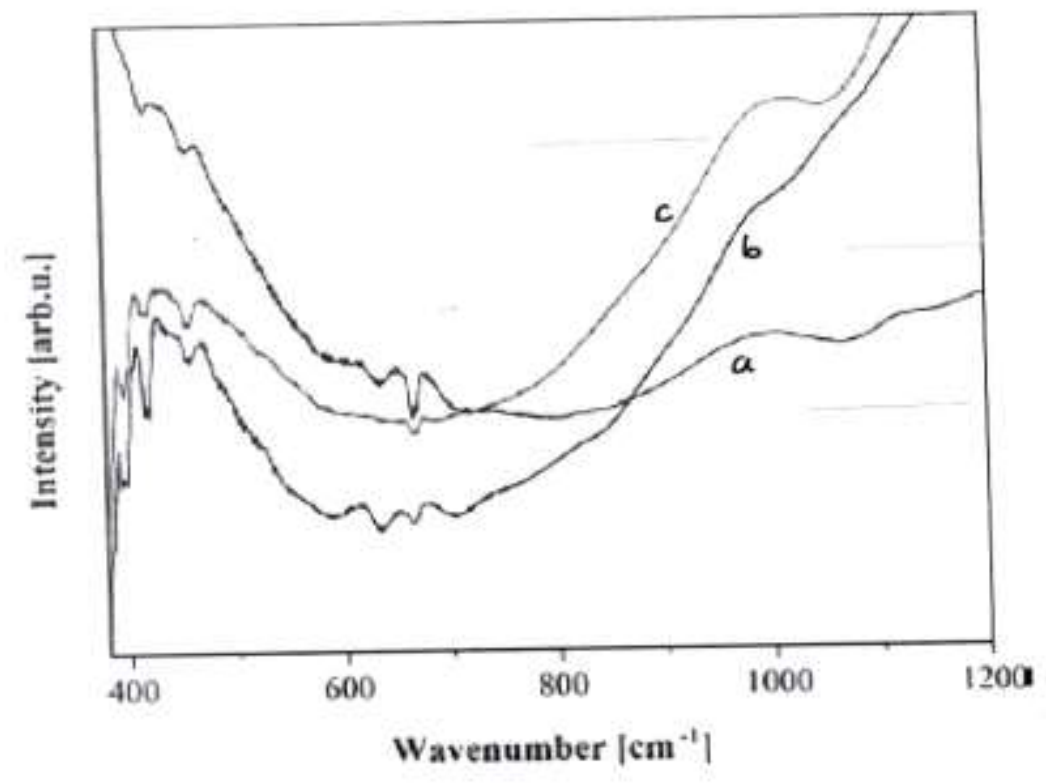

Fig.3 - FTIR spectra of $\mathrm{Al}_{2} \mathrm{O}_{3}$ films post annealed at different temperatures

(a) $550^{\circ} \mathrm{C}$ (b) $450^{\circ} \mathrm{C}$ (c) $350^{\circ} \mathrm{C}$

Figure 3 show FTIR spectra of $\mathrm{Al}_{2} \mathrm{O}_{3}$ thin films formed at different temperature. The IR line at $396.5 \mathrm{~cm}-1$ and $405.7 \mathrm{~cm}-1$ are assigned to the stretching vibration of Al-O and to lattice. The absorption bands in the range of $420-460 \mathrm{~cm}-1$ are due to Al-O bonding some authors observed bands in the same spectral range for $\mathrm{Al}_{2} \mathrm{O}_{3}$ powders sintered at temperature $160 \mathrm{C}-750 \mathrm{C}$ they claim that they are active and forbidden modes of $\alpha-\mathrm{Al}_{2} \mathrm{O}_{3}$ [9].Absorption lines located at 586 and 633 cm-1 are related to stretching bonding in AlO6.The band appearing in all spectra at $668 \mathrm{~cm}-1 \mathrm{can}$ be attributed to O-Al-O vibrations the weak $710 \mathrm{~cm}-1$ line is due to $\mathrm{Al}-\mathrm{O}$ of $\mathrm{AlO} 4$.After thermal treatment at $550 \mathrm{C}$ a broad absorption band appeared at $1060 \mathrm{~cm}-1$. This IR band indicate a presence of Al-O-Si band or Al-O-Al. The IR band at $828 \mathrm{~cm}-1$ reported by other authors is assigned to crystalline aluminum oxide has not been found in our spectra. The appearance of broad bands may be due to amorphous oxide matrix. The higher annealing temperatures lead to weakening and disappearance of the absorption bands characteristics for $\mathrm{OH}$-vibration and carbon containing molecules. 


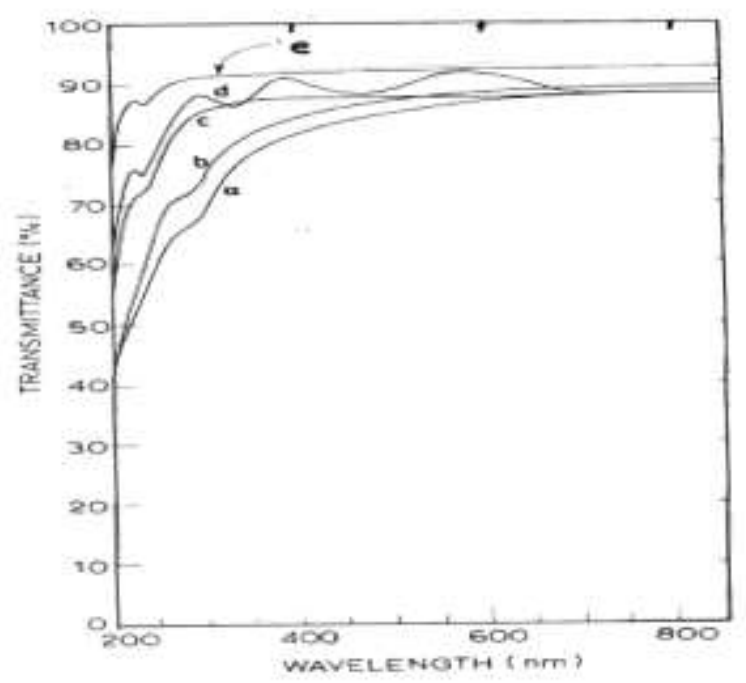

Fig.4- Transmission spectrum of $\mathrm{Al}_{2} \mathrm{O}_{3}$ films post annealed at different temperatures (a) $300^{\circ} \mathrm{C}$ (b) $350^{\circ} \mathrm{C}$ (c) $450^{\circ} \mathrm{C}$ (d) $550^{\circ} \mathrm{C}$ (e) bare substrate

The transmission spectra (fig-4) for the $\mathrm{Al}_{2} \mathrm{O}_{3}$ thin films post annealed at $550 \mathrm{C}$ exhibited interference fringes. The optical transmission spectra of the $\mathrm{Al}_{2} \mathrm{O}_{3}$ thin films indicate an average transmittance of about $78 \%$ to $86 \%$ at $400 \mathrm{~nm}$. Higher transmittance (about 90\%) at all wavelengths was observed for the films post annealed at $550 \mathrm{C}$. The absorption coefficient $(\alpha)$ was calculated from the transmission spectra. The absorption coefficient of various films was $104 \mathrm{~cm}-1$. The linear portion of the curve was extrapolated to meet of energy axis at $\alpha=0$ and the corresponding value of energy was taken as the optical band gap. This was found to be in the range of 5.40-5.70 eV (Fig-5)

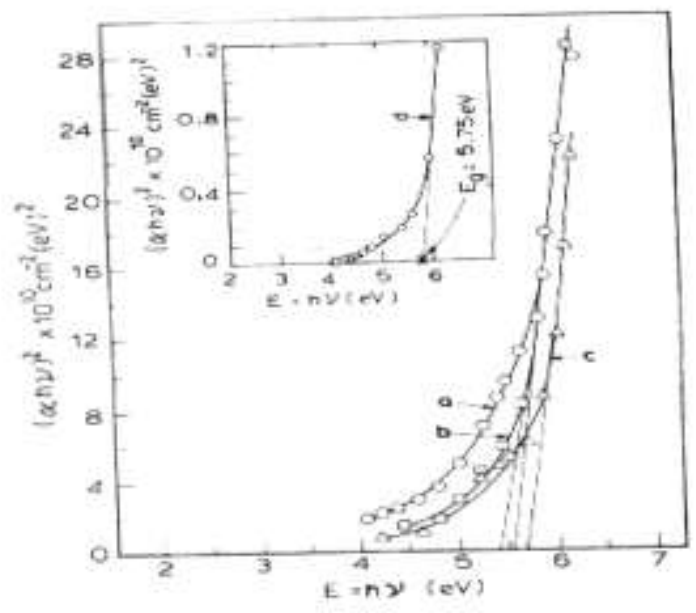

Fig.5 - $(\alpha h v)^{2}$ vs hv plot for $\mathrm{Al}_{2} \mathrm{O}_{3}$ films deposited at different temperatures (a) $300^{\circ} \mathrm{C}$ (b) $350^{\circ} \mathrm{C}$ (c) $450^{\circ} \mathrm{C}$ (d) $550^{\circ} \mathrm{C}$

with increase of annealing temperature. The refractive index was calculated using the envelope method 
(fig-6).It was found that the refractive index decreased with increase in wavelength and becomes almost constant at higher wavelength beyond $400 \mathrm{~nm}$.

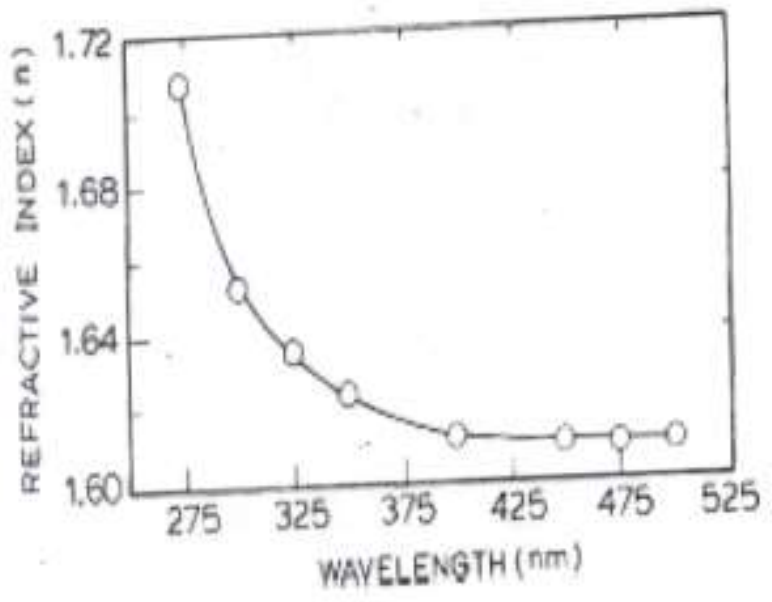

Fig.6- Variation of refractive index with wavelength for $\mathrm{Al}_{2} \mathrm{O}_{3}$ films post annealed at $550^{\circ} \mathrm{C}$ Conclusion:

$\mathrm{Al}_{2} \mathrm{O}_{3}$ thin films were deposited by sol gel dip coating method using the acrylamide route. $\mathrm{X}$-ray diffraction studies indicated all the peaks corresponding to single phase $\gamma-\mathrm{Al}_{2} \mathrm{O}_{3}$.The optical transmittance spectra of the $\mathrm{Al}_{2} \mathrm{O}_{3}$ thin films indicate an average transmission of about $90 \%$ and with a band gap $5.75 \mathrm{eV}$ can be obtained.

\section{Reference:}

[1]Y.Chiba,A.Islam,Y.Watanable

[3] G.Ramanathan,R.John Xaier and K.R.Murali "Sol gel dip coated Tin Oxide thin films" Thin film Technology 50 (2012)10588-10590.

[4] G.Ramanathan,R.John Xaier and K.R.Murali "Dye sensitized solar cells with ITO films prepared by the Acrylamide sol gel route” IOSR journal of Applied physics issue 6 Vol 2 (2013) 47-50.

[5]K.Tennakone, G.R.R.Kumara I.R.M.Kottegoda, V.S.P.erera, Chem.Commun.15 (1999).

[6] K.Sayama,H.Suguhara,H.Arakawa,Chem.Mater 10 (1998) 2825.

[7] Easwaramoorthi Ramansamy,Won Jae,Lee Dong Yoon Lee,Jae Sung,Song,Journal of power source 165 (2007) 446.

[8] J.Y.Liao,K.C.Ho,Sol.Energy Mater,Sol.cells 86 (2005) 229.

[9] W.U.Huynh,J.J.Dittmer,A.P.Alivisatos science 295 (2002) 2425. 